\title{
Kobieta w tradycyjnych przysłowiach i powiedzeniach angielskich i polskich
}

\section{Wstęp}

U podstaw pojęcia językowego obrazu świata leży teza, iż język wyznacza granicę naszego poznania i stanowi swoistą interpretację świata. Myśl ta, podjęta przez filozofów i językoznawców takich jak Humboldt, Weisgerber, Herder, Wittgenstein, znalazła potwierdzenie w badaniach etnolingwistów Sapira i Whorfa. Cechą języka jest ,aspektowność, wybiórczość, niepełność w odniesieniu do ujmowanej rzeczywistości bądź jej elementów" (Anusiewicz 1990: 95). W języku nie mamy zatem do czynienia z prostym odbiciem desygnatów, a raczej ze strukturami o charakterze stereotypów, na co zwrócił uwagę Putnam, włączając stereotyp do opisu znaczenia słowa.

$\mathrm{Na}$ gruncie polskim tematykę stereotypów językowych i językowego obrazu świata podjął Bartmiński, twórca pojęcia definicji kognitywnej, która ma zdać sprawę „ze sposobu pojmowania przedmiotu przez mówiących danym językiem” (Bartmiński 1988: 169). Na językowy obraz zjawiska składają się, oprócz cech desygnacyjnych, cechy konotacyjne, które Tokarski zdefiniował jako „dopełniającą treść słowa, nakładającą się na jego znaczeniowy komponent intelektualny” (Tokarski 1988: 35). Według Grzegorczykowej konotacje semantyczne to „cechy (oceny, emocje) kojarzone przez ogół mówiących (lub przez niektóre środowiska, a nawet jednostki) $\mathrm{z}$ desygnatami nazw, utrwalone w pewnych faktach językowych (metaforach, derywatach, frazeologizmach)" (Grzegorczykowa 1999: 44). Jak zauważa Maćkiewicz, językowy obraz świata to odbicie doświadczenia poznawczego danej społeczności, w którym współistnieją elementy stare i nowe, dlatego ma on charakter ahistoryczny i heterogeniczny, ,składają się nań bowiem elementy pochodzące z różnych etapów rozwoju ludzkiego myślenia i z różnych źródeł" (Maćkiewicz 1999: 196). 
W świetle powyższych rozważań pragnę przedstawić podsumowanie badań porównawczych językowego obrazu kobiety w językach angielskim i polskim, poświęconych tym elementom językowego obrazu kobiety, które zapisane są w najbardziej tradycyjnej warstwie języka, jaką stanowią przysłowia. Jakie cechy konotacyjne utrwalone są w przysłowiach i powiedzeniach obu języków? W jakim stopniu obrazy kobiety ukształtowane przez wieki we względnej bliskości kulturowej są do siebie podobne, a w jakim stopniu oddala je od siebie odrębność języków angielskiego i polskiego? Celem artykułu jest udzielenie odpowiedzi na te pytania wraz z przykładami wybranymi z wielkiego bogactwa frazeologii dotyczącej kobiety w obu językach.

\section{Konotacje utrwalone w angielskich i polskich przysłowiach i powiedzeniach o kobietach}

Wśród cech, które przypisują kobiecie angielskie i polskie przysłowia i powiedzenia ${ }^{1}$, wyróżnia się gadatliwość. Wiele przysłów i powiedzeń dotyczy tej wady: Where women are, are many words (Gdzie są kobiety, tam jest wiele słów), Where there are women, there is much tattling (Gdzie są kobiety, tam jest wiele gadania), Miele językiem jak baba, Baba w progi, cisza w nogi, Niewiasta każda wielomówna. Cechę tę zestawiano w obu językach z hałaśliwością ptactwa i jarmarku: Women and magpies are always prattling (Kobiety i sroki ciągle paplają), Three women (and a goose) make a market (Trzy kobiety (i gęś) tworzą jarmark), Trzy gęsi, dwie niewieście uczynity jarmark w mieście, Gdzie się zejda trzy białogłowy, tam już jarmark gotowy. Mowa kobiet jest niewiele warta: Women will say anything (Kobiety mówią cokolwiek), A woman's tounge wags like a lamb's tail (Język kobiety lata jak ogon baranka), babskie gadanie. Język kobiety angielskiej jest niezwykle żywotnym organem: A woman's tounge is the last thing about her that dies (Język kobiety jest ostatnią rzeczą, która w niej umiera), When a man dies the last thing that moves is his heart; in a woman her tounge (Kiedy umiera mężczyzna, ostatnią rzeczą, która się w nim porusza, jest jego serce, w kobiecie jej język). W przysłowiach polskich język jest orężem kobiety: Język niewiast gorzej miecza siecze, Wót rogami, baba językiem kole.

Gadatliwość kobiet idzie w parze z kłótliwością: A woman's answer is never to seek (O odpowiedź kobiety nie trzeba się nigdy starać), Women will have the

${ }^{1}$ Przysłowia i powiedzenia pochodzą z następujących źródeł: The Oxford Dictionary of English Proverbs, Oxford English Dictionary, Thesaurus of Traditional English Metaphors, J. Gluski, Proverbs; J. Krzyżanowski, Nowa księga przysłów i wyrażeń przysłowiowych polskich; J. Krzyżanowski, Mądrej głowie dość dwie słowie. Pięć centuryj przysłów polskich, S. Skorupka, Stownik frazeologiczny języka polskiego. Tłumaczeń z języka angielskiego dokonała na użytek artykułu autorka. 
last word (Kobieta musi mieć ostatnie słowo), Z babski mowy swar gotowy, Ukróć człeku babie ozór, a stracisz do kłótni pozór. Rozzłoszczona kobieta porównana jest w języku angielskim do osy: Women are like wasps in their anger (Kobiety w gniewie są jak osy), polszczyzna zestawia ją z diabłem: Babę rozdrażnić to gorzej niż diabła. Inną konsekwencją gadatliwości jest nieumiejętność zachowania tajemnicy: Woman conceals what she knows not (Kobieta ukrywa to, czego nie wie), Women and bairns lain what they know not. But what they know, they'll blab out (Kobiety i dzieci ukrywają to, czego nie wiedzą. Zaś to, co wiedzą, zawsze wygadają). Dyskrecja jest u kobiet cnotą bardzo rzadką, zatem szczególnie cenioną: Silence is the best ornament of a woman (Milczenie jest najlepszą ozdobą kobiety). Podobnie polska kobieta ma skłonność do plotkowania: Zachować co w sekrecie najciężej jest kobiecie, Po catym mieście chodza plotki niewieście, Jak wie co baba, to wie $i$ wójt, i cała gromada. Cecha ta także odwodzi je od pracy: Gdzie dużo bab, tam robota nic nie warta.

Przysłowia przypisują kobiecie złą naturę: If a woman were as little as she is good, a pease-cod would make her a gown and a hood (Jeśli kobieta byłaby tak mała, jak jest dobra, strączek grochu starczyłby jej za płaszcz z kapturem), Dwie tylko dobre niewiasty na świecie: jedna się zgubiła, a druga się znaleźć nie może, Niewiasta - zła rzecz. Według przysłów angielskich sfera duchowa jest u kobiet bardzo ograniczona: Women have no souls (Kobiety nie mają duszy), The souls of women are so small, that some believe th' have none at all (Dusze kobiet są tak małe, iż niektórzy wierzą, że ich wcale nie ma), przysłowia polskie zaś podkreślają moralną słabość kobiety: Nie masz kobiety, której by zło nie skusiło, Nie ustrzeżesz niewiasty świerzbiącego tona. Kobieta jest moralnie gorsza od mężczyzny, zwłaszcza w języku angielskim: Bad woman is worse than bad man (Zła kobieta jest gorsza niż zły mężczyzna), A man of straw is worth a woman of gold (Mężczyzna ze słomy jest wart kobiety ze złota), Women in mischief are wiser than men (W złych rzeczach kobiety są mądrzejsze od mężczyzn), Lepszy jest grzech męski niż cnota niewieścia. Wobec przedstawicielek swojej płci kobiety są nieszczere i zawistne: Dead woman will have four to carry her (Jedna zmarła kobieta znajdzie cztery, które ją poniosą), Baba babę catuje, a za oczy obgaduje, Przyjaźn dwóch kobiet jest tylko złościa przeciw trzeciej.

W wielu przysłowiach polskich kobieta jest gorsza od diabła: Baba gorsza jak diabel, Gdy się baba rozpanoszy, to i diabła wypłoszy, Z baba i z diablem lepiej nie zaczynać, a jej natura spokrewniona jest z diabelską: Baba, żaba, diabet trzeci to rodzone dzieci, Baba z piekta rodem, Nie wdawaj się z kobieta, co ma diabła w oczach. Porównanie z diabłem odnajdziemy też w przysłowiu angielskim: Man, woman and devil are the three degrees of comparison (Mężczyzna, kobieta i diabeł to trzy kolejne stopnie). W obu językach kobieta może stać się narzędziem szatana: Women are the devil's nets (Kobiety są sieciami diabła), Czart przez biała głowe wiele złego sprawi, Woda mtynem, wiatr śmigami, a zła baba diabet obraca. Zwłaszcza jednak stara kobieta nie może być dobra: There is no such thing 
as good small beer, good brown bread, or a good old woman (Nie ma czegoś takiego jak dobre małe piwo, dobry ciemny chleb i dobra stara kobieta), Dobre sa baby, ale nie stare, Gdzie stara baba, tam i diabet mieszka, Stare baby wiedza, co w piekle warza i jedza. Starość oceniana jest bardziej negatywnie u kobiet niż u mężczyzn: A man is as old as he feels, and a woman as old as she looks/Kobieta ma tyle lat, na ile wyglada, mężczyzna - na ile się czuje ${ }^{2}$.

W obu językach kobieta postrzegana jest jako niszczycielski żywioł: Fire, sea, woman, three evils (Ogień, morze i kobieta, trzy zła), Niewiasta, ogień, morze - to chodzi w jednej sforze, Ogień, morze, niewiasta - trzy złe rzeczy. W angielskich przysłowiach kobiety są przyczyną sporów między mężczyznami: Women and dogs set men together by the ears (Kobiety i psy są przyczyną męskich waśni), No war without a woman (Nie ma wojny bez kobiety). Mogą stać się nałogiem doprowadzającym mężczyzn do ruiny moralnej i finansowej: Women and wine, game and deceit, make the wealth small, and the wants great (Kobiety i wino, hazard i oszustwo pomniejszają majątek i zwiększają żądze), Women, wine and dice will bring a man to lice (Kobiety, wino i gra w kości doprowadzą mężczyznę do wszy), Play, women, and wine undo men laughing (Gry, kobiety i wino odbierają mężczyźnie chęć do śmiechu), Dally not with women and money (Nie igraj z kobietami i z pieniędzmi). W mniejszym stopniu wątek ten obecny jest w polszczyźnie: Kto lubi ubierać kobietki, tego one za to rozbieraja, Utrata jest wieczna, kobieta wszeteczna.

W przysłowiach angielskich kobiety są dla mężczyzn źródłem przyjemności: Who loves not wine, woman and song, he is a fool his all life long (Kto nie kocha wina, kobiety i śpiewu, ten jest głupcem przez całe życie), Let us have wine and women, mirth and laughter (Bawmy się winem i kobietami, weselmy się i śmiejmy). Są także traktowane jak obiekt do zdobycia: All women may be won (Wszystkie kobiety mogą być zdobyte), A woman kissed is half won (Pocałowana kobieta jest w połowie zdobyta), Woman that parleys is half gotten (Kobieta, która pertraktuje, jest w połowie zdobyta). W polskim przysłowiu również odnajdziemy motyw zdobywania kobiety, choć wyrażony inaczej: Mądry to ptaszek, niewiasta, nie da się tak tatwo złowić.

Jak ostrzegają przysłowia angielskie, uroda kobiet naraża je na moralne niebezpieczeństwo: Fair woman and a slashed gown find always some nail in the way (Ładna kobieta i rozcięta suknia zawsze znajdą jakiś gwóźdź na drodze), Woman and cherry are painted for their own harm (Kobieta i wiśnia pomalowane są na swą własną zgubę). Do upadku kobiety przyczynia się też jej próżność: A woman that loves to be at the window, is like a bunch of grapes on the highway (Kobieta, która lubi wyglądać przez okno, jest jak kiść winogron przy gościńcu), Tell a woman she is fair, and she will soon turn fool (Powiedz kobiecie, że jest

${ }^{2} \mathrm{Na}$ odmienne standardy w ocenie płci w porzekadłach polskich, zarówno w kontekście wyglądu, jak i w wymiarze moralnym, wskazują M. Karwatowska i J. Szpyra-Kozłowska w pracy Lingwistyka płci. Ona i on w języku polskim (Karwatowska, Szpyra-Kozłowska 2010: 55). 
ładna, a ona wkrótce zgłupieje). Przysłowia angielskie oskarżają kobiety dbające o urodę o niemoralność: A woman that paints, puts up a bill that she is to be let (Malując się, kobieta ogłasza, że jest do wynajęcia) lub bardziej dosłowna wersja: For she that paints will doubtless be a whore (Bowiem ta, która się maluje, jest bez wątpienia nierządnicą). Mężczyzna nie powinien dać się oszukać tym zabiegom: Let no woman's painting breed thy stomach's fainting (Nie pozwól, żeby makijaż kobiety odbierał ci siły). Cnotliwość jest ceniona wyżej niż uroda: Fair woman without virtue is like palled wine (Ładna, lecz niecnotliwa kobieta jest jak zepsute wino), w polszczyźnie ponad urodę wyniesiona jest mądrość: Niewiasta piękna a głupia jest jak złote kolce w pysku świni. Również w polskich przysłowiach uroda i dbanie o wygląd źle wpływają na kobiety: Piękna miska jeść ci nie da, Kobieta, co się stroi do poludnia, od potudnia mało warta, Gtupia kobietę poznasz po spódnicy, jednak brak urody jest wielką wadą: Nie pomoże bielidło, kiedy baba straszydto.

Kobiety są istotami słabszymi: $A$ woman is the weaker vessel (Kobieta jest słabszym naczyniem), Niewiastę zwyciężyć - nie męstwo. Przysłowia angielskie porównują delikatność kobiety z kruchością szkła: Woman and a glass are ever in danger (Kobieta i szkło są zawsze $\mathrm{w}$ niebezpieczeństwie), Truely woman is of glass, therefore no man ought to try if she broke or not might be (Istotnie, kobieta jest ze szkła, dlatego żaden mężczyzna nie powinien próbować, na ile jest wytrzymała). Słabość kobiety ma też wymiar moralny, stłuczone szkło jest obrazem utraty cnoty i upadku kobiety: Women having lost their chastity are like broken glasses which are good for nothing (Kobiety, utraciwszy swą cnotę, są jak stłuczone szkło, które nie nadaje się do niczego). Równocześnie ważny rys w językowym obrazie kobiety angielskiej stanowią powiedzenia wyrastające z kultury dworskiej, które odnoszą się do kobiety z kurtuazją jako do istoty subtelnej, wymagającej specjalnego traktowania: All women are angels (Wszystkie kobiety są aniołami), Women and music should never be dated ( $\mathrm{O}$ wieku kobiet i muzyki nie powinno się mówić), Three wonders of England, the churches, the women, the wool (Trzy cuda Anglii: kościoły, kobiety, wełna), England is the paradise of women (Anglia jest rajem kobiet). W mniejszym stopniu rys ten zaznacza się w powiedzeniach polskich: kobieta - aniol, My rzadzim światem, a nami kobiety. Natomiast specyfiką językowego wizerunku kobiety w przysłowiach polskich jest obraz silnej kobiety, o solidnej posturze i mocnym charakterze: Baba jak rzepa, Baba jak tur/Kozak/Tatar, Kobieta jak turoń, Baba gruba, chtopa chluba, Kobieta przy kości, Baba jak stóg siana. Taka krzepka kobieta bywa też przykra i uciążliwa dla otoczenia: Herod baba, Baba z wozu, koniom lizej.

Wiele przysłów mówi o tym, iż miejscem kobiety jest dom, a jej powołaniem praca w domu i życie rodzinne: The good housewife's candle never goes out (Lampka dobrej gospodyni nigdy nie gaśnie), Babska droga od pieca do proga, Kobiecie bez fartucha jak krowie bez ogona. Przysłowia zauważają domowy trud kobiety: Woman's work is never at an end/A woman's business is never done (Pra- 
ca kobiety nie ma końca), Robota kobiecka nieskończona, Robota kobiecka choć nieznaczna, ale smaczna. W domu kobieta jest niezastąpiona: Woeful is a household that wants a woman (Nieszczęsny ten dom, w którym brakuje kobiety), Nie masz niewiast $w$ naszej chacie. Wśród przysłów polskich odnajdziemy także takie, które mówią o powołaniu kobiet do macierzyństwa: Dobry kobicie dziecko - jak koniowi owies, Babie na zime pierzyna, na lato dziecko. Z powyższych powodów kobieta, mimo wielu wad, jest bardzo potrzebna: $Z$ baba jest źle, ale bez baby jeszcze gorzej, Z kobietami wielka bieda, lecz bez kobiet żyć się nie da, Kobiety sa zlem koniecznym/Women are necessary evils.

O niższym statusie finansowym kobiet w małżeństwie świadczą angielskie przysłowia: A married woman has nothing of her own but her wedding-ring and her hair-lace (Zamężna kobieta nie posiada niczego poza obrączką i wstążką), Women must have their wills while they live, because they make none when they die (Wola kobiet musi być spełniona za ich życia, ponieważ nie spisują one ostatniej woli). Przysłowia angielskie zauważają, że kobiety są niedoskonałe, potrzebują nadzoru: A ship and a woman are ever repairing (Statek i kobieta wymagają ciągłych napraw), Women and ships are never so perfect but still there is something to be amended (Kobiety i statki nie są nigdy doskonałe, wciąż potrzebują poprawek). W przysłowiach obu języków mężczyzna powinien karać kobietę fizycznie, dla jej dobra: A woman, an ass and a walnut tree, the more you beat them, the better they'll be (Kobieta, osioł i orzech, im więcej w nie uderzasz, tym będą lepsze), Niewiasta karności potrzebuje, Jak się baby nie bije, to jej wątroba gnije, Jak się baby z rana nie zbije, to cały dzień głupia chodzi. Kobiety jednak wymykają się spod męskiej kontroli: Strzec niewiasty nalewać w piasty, Łacniej wór pchet upilnować, niż jedna kobietę, czasami nawet przejmują rolę dominującą: She wears the breeches (To ona nosi spodnie), Men get wealth and women keep it (Mężczyźni zdobywają majątek, kobiety nim zarządzają).

W obu językach przysłowia postrzegają kobiety jako zwodnicze i zmienne: Who has a woman has an eel by the tail (Mieć kobietę to jak trzymać węgorza za ogon), A woman's mind and winter wind change often (Zdanie kobiety i zimowy wiatr często się zmieniają), Women are as wavering as the wind (Kobiety są zmienne jak wiatr), Trzymać kobietę za słowo, a piskorza za ogon - na jedno wychodzi, Ani na wsi, ani w mieście nie trzeba wierzyć niewieście, I umarlej niewieście nie ma być wierzono. Kobiety przebiegle posługują się łzami: Women laugh when they can, and weep when they will (Kobiety śmieją się, kiedy mogą, a płaczą, kiedy chcą), Trust not a woman when she weeps (Nie ufaj kobiecie, kiedy płacze), Łzy — broń kobieca, Łzy kobiety sa najmocniejszym szturmem na mężczyznę, Płaczem kobieta wszystko z mężczyzna zrobić potrafi.

Uczuciowość jest wartością docenianą u kobiety: Kobieta bez serca, mężczyzna bez odwagi - wiele niewarci. Kobiety mają jednak skłonność do uczuć skrajnych: Woman either loves or hates in extremes (Kobieta albo bezgranicznie kocha, albo bezgranicznie nienawidzi), A woman either loves or hates, there is no 
third (Kobieta albo kocha, albo nienawidzi, nie ma trzeciego sposobu), Kobieta czy kocha, czy nienawidzi - nigdy w miare, Nie ma ziela na babskie wesela, nie ma rutki na babskie smutki, Niewiasta nie ma w niczym miary. Intelekt nie jest mocną stroną kobiety: When an ass climbs a ladder we may find wisdom in women (Odnajdziesz mądrość w kobietach nie prędzej, niż osioł wdrapie się na drabinę), Because is a woman's reason ('Dlatego' to kobiece wythumaczenie), $U$ kobiety włos dtugi, a rozum krótki, Głupia baba gorsza niż szarańcza. Z tych też powodów kobiety nie powinny zarządzać ani brać udziału w polityce: Women in state affairs are like monkeys in glass-shops (Kobiety w sprawach państwowych są jak małpy w sklepie ze szkłem), Nie baby rej wodza w senacie, Rzad niewieści nie czyni czci, Gdzie baba rządzi, tam czeladź błądzi.

Zgodnie $\mathrm{z}$ angielskim przysłowiem wykształcenie nie jest kobiecie potrzebne, wręcz może być szkodliwe: A morning sun and a wine-bred child, and a Latin-bred woman seldom end well (Poranne słońce, dziecko, które zna smak wina i kobieta, której nieobca łacina - rzadko dobrze kończą). Polskie powiedzenia zwracają uwagę na fakt, iż kobiety nie potrafią przewidywać konsekwencji swoich czynów, przez co narażają się na kłopoty: Nie miała baba kłopotu, kupiła sobie prosię, Masz babo placek! Także porady kobiet nie są cenione: Kto stucha baby, pójdzie na dziady, Sto bab, sto rad. Jednak przysłowia angielskie zauważają intuicję kobiet, dzięki której kobiety czasem rozumieją więcej niż mężczyźni i warto ich posłuchać: A woman's advice is no great thing, but he who won't take it is a fool (Rada kobiety to nic ważkiego, ale kto jej nie słucha, jest głupcem), $A$ woman has an eye more than a man (Kobieta ma o jedno oko więcej niż mężczyzna). W polszczyźnie docenia się rady kobiet starszych: Stare baby do porady, mtode do uciechy, Do baby na porady.

Według przysłów angielskich kobiety są fałszywe, skłonne do intryg i oszustwa: Such a plot must have a woman in it (Za taką intrygą musi stać kobieta), No mischief but a woman or a priest is at the bottom of it (Nie kryje się za tym żadne inne oszustwo, tylko kobieta albo ksiądz). Kobiety angielskie łatwo znajdują wymówki: Find a woman without an excuse, and find a hare without a meuse (Znajdź kobietę bez wymówki, znajdź zająca bez kryjówki). W językowym obrazie kobiety polskiej szczególne miejsce zajmuje spryt: Babi naród zawsze chytry, Kobiety, choć się nie ucza w szkole, przecię wywioda w pole, Możesz mówić zawżdy śmiele, iż niewiasta chytre ziele. Dlatego trudno jest oszukać kobietę: Baby trudno oszukać, Dtugo ten pokuka, kto babę oszuka, Trzeba rano wstać, żeby babę oszukać. Sam diabeł nie daje sobie z nią rady: Czart z baba nie poradzi, Baby i diabet nie oszuka, bowiem kobieta jest sprytniejsza od diabła: Bies tam nie dowiedzie, gdzie baba dojedzie, Gdzie diabet nie może, tam babę pośle. Z kobietą nikt nie da sobie lepiej rady niż druga kobieta: Na babę nie ma jak druga baba.

Bardzo wyrazistą cechą w polskim obrazie językowym kobiety jest również upór: Na babski upór nie ma lekarstwa, Każda baba z natury uparta, Baba swoje, czort swoje, Kobiety rozumem nie przeprzesz, Łatwiej wroga pokonać, niż kobiete 
przekonać. W przysłowiach polskich utrwalona jest także kobieca ciekawość: Zaspokoić ciekawość kobiety jest to napetnić woda przetak, Babska ciekawość jest jak beczka bez dna, Ciekawy jak baba, Ciekawość nałogiem niewiasty, tchórzliwość: I baba się tego nie zlękła, Tchórzliwy jak baba i łakomstwo: Kobiety się biora na stodycze, jak ryby na wędkę.

\section{Podsumowanie — językowe obrazy kobiety w przysłowiach i powiedzeniach angielskich i polskich}

Jak wykazała analiza, językowe obrazy kobiety zapisane w przysłowiach polskich $\mathrm{i}$ angielskich są do siebie podobne i w przeważającej mierze negatywne. Większość przysłów jest „wyrazem tradycyjnego mizoginizmu, niechęci do płci niewieściej, tak znamiennego dla literatury ludowej, a do niej przecież przysłowie integralnie należy" (Krzyżanowski 1994: 293)³. Kobieta w przysłowiach obu języków jest gadatliwa, kłótliwa i ma słabość do plotkowania. Ma złą naturę, gorszą niż mężczyzna, bliską diabłu, który może się nią posługiwać. Kobieta bywa niszczycielskim żywiołem, porównywana z ogniem, może stać się zgubą dla mężczyzny. Uroda, choć jest niewątpliwie zaletą, ma zły wpływ na kobietę, popycha ją ku próżności i niemoralności. Starość kobiety łączona jest nie tylko z utratą urody, lecz także z negatywną oceną charakteru. Kobieta w przysłowiach jest słabsza moralnie i fizycznie od mężczyzny, który powinien ją kontrolować i karać dla jej dobra. Ponadto kobietę charakteryzuje emocjonalność, skrajność w uczuciach, zmienność i płaczliwość. Przysłowia ukazują, iż cechy te bywają wykorzystywane przez płeć piękną w celu manipulacji. Kobiety nie powinny sprawować władzy z powodu nisko ocenianych walorów intelektualnych. Natomiast sferą, w której docenia się wartość kobiety, jest dom, domowe obowiązki zaś to kobieca praca, w której jest niezastąpiona.

Przysłowia angielskie traktują kobietę bardziej przedmiotowo i surowo. Kobieta jest przyczyną waśni, obiektem do zdobycia, źródłem przyjemności. Kobiety dbające o swoją urodę są niemoralne, brak cnotliwości jest gorszą wadą niż brak urody. Kobiety są fałszywe i skłonne do intryg. Podrzędny status kobiety wobec mężczyzny zaznacza się w przysłowiach angielskich o wiele mocniej, kobiety są zależne finansowo od mężczyzn, kształcenie kobiet uznane jest za niepotrzebne. Przysłowia angielskie doceniają natomiast kobiecą intuicję, a także traktują kobietę z kurtuazją znamienną dla kultury dworskiej. W przysłowiach polskich kobiety postrzegane są bardziej podmiotowo i z większą dozą ludowego

3 Zdaniem R. Łobodzińskiej negatywny stereotyp kobiety ma „źródła w kulturze europejskiej, która była i jest kulturą męską, a mizoginizm odgrywał w niej istotną rolę i przejawiał się w różnych sferach życia" (Łobodzińska 1994: 184). Podobnie M. Karwatowska i J. Szpyra-Kozłowska (2010) zwracają uwagę na asymetrie rodzajowo-płciowe w wielu językach europejskich. 
humoru ${ }^{4}$. Zwraca uwagę duża liczba przysłów zestawiających kobietę z diabłem. Choć w obu językach zaznacza się niezależność i chęć dominacji u kobiet, spryt i upór polskiej kobiety pozwala jej skutecznie walczyć o swoje cele. W językowym obrazie kobiety polskiej obecne są takie elementy, jak żywotność, tężyzna fizyczna, powołanie do macierzyństwa, lecz także głupota, wścibskość, tchórzostwo i łakomstwo, które składają się na wielobarwną mozaikę kobiecej natury.

Przysłowia tworzą tę warstwę języka, która w dużej mierze już przeszła lub przechodzi do historii. Jak zaznacza Maćkiewicz, rewolucjom społecznym i obyczajowym nie towarzyszą rewolucje językowe. ,Język ewoluuje wolniej niż ludzkie myślenie" (Maćkiewicz 1999: 195). Dlatego znajomość obrazów kobiety, a w szerszej perspektywie językowych obrazów świata utrwalonych w przysłowiach, pozwala bardziej świadomie ocenić skalę przewartościowań zachodzących w języku i kulturze.

\section{Bibliografia}

Anusiewicz J. (1990), Językowo-kulturowy obraz kota w polszczyźnie, [w:] Etnolingwistyka, t. 3, red. J. Bartmiński, Lublin, s. 95-141.

Bartmiński J. (1988), Definicja kognitywna jako narzędzie opisu konotacji, [w:] Konotacja, red. J. Bartmiński, Lublin, s. 169-183.

Gluski J. (1971), Proverbs, Amsterdam-London-New York.

Grzegorczykowa R. (1999), Pojęcie językowego obrazu świata, [w:] Językowy obraz świata, red. J. Bartmiński, Lublin, s. 39-46.

Jędrzejko E. (1994), Kobieta w przysłowiach, aforyzmach $i$ anegdotach polskich. Konotacje $i$ stereotypy, [w:] Pteć w języku i kulturze, red. J. Anusiewicz, K. Handke („Język a Kultura” 9), Wrocław, s. 159-172.

Karwatowska M., Szpyra-Kozłowska J. (2010), Lingwistyka ptci. Ona i on w języku polskim, Lublin. Krzyżanowski J. (1994), Mądrej głowie dość dwie stowie. Pięć centuryj przystów polskich i diabelski tuzin z hakiem, Warszawa.

Krzyżanowski J. $(1969,1970)$, Nowa księga przystów i wyrażeń przystowiowych polskich, Warszawa.

Łobodzińska R. (1994), Jaka jest kobieta w języku polskim?, [w:] Pteć w języku i kulturze, red. J. Anusiewicz, K. Handke („Język a Kultura” 9), Wrocław, s. 181-186.

Maćkiewicz J. (1999), Wyspa - językowy obraz wycinka rzeczywistości, [w:] Językowy obraz świata, red. J. Bartmiński, Lublin, s. 193-206.

The Oxford Dictionary of English Proverbs (1970), Oxford.

The Oxford English Dictionary (1975), London.

Skorupka S. (1985), Stownik frazeologiczny języka polskiego, Warszawa.

Tokarski R. (1988), Konotacja jako składnik treści stowa, [w:] Konotacja, red. J. Bartmiński, Lublin, s. 35-53.

Wilkinson P.R. (1993), Thesaurus of Traditional English Metaphors, London-New York.

4 Dominujący rys ,żartobliwej wyrozumiałości” i ,rubasznej familiarności” dostrzega E. Jędrzejko w obrazie kobiety na podstawie analizy przysłów, aforyzmów i anegdot polskich (Jędrzejko 1994: 170). 


\section{The linguistic view of woman in English and Polish proverbs}

\section{Summary}

The aim of this paper is to present the linguistic view of woman in English and Polish proverbs. According to philosophers and linguists whose ideas shaped the concept of the linguistic worldview and cognitive definition, the language we use provides us with a specific interpretation of the world. Cognitive definitions should account for the way language users perceive particular phenomena. This article looks at connotative features encoded in English and Polish proverbs about women, which are sets of implicit judgments that build the linguistic stereotype of woman. The analysis of the material shows that the linguistic stereotypes of woman in English and Polish proverbs are to a great extent similar and predominantly negative. Yet, there are language specific differences concerning the overall attitude towards women, as well as relative salience of particular features.

Keywords: linguistic view of woman, connotative feature, proverb, linguistic stereotype 